\title{
Differential Response to Floral Infection by Botrytis cinerea within the Genus Pelargonium
}

\author{
Michael S. Uchneat ${ }^{1}$, Kathryn Spicer ${ }^{2}$, and Richard Craig ${ }^{3}$ \\ Department of Horticulture, The Pennsylvania State University, University \\ Park, PA 16802-4200
}

Additional index words. geranium, floriculture, gray mold, Botrytis blight

\begin{abstract}
The objective of this study was to identify geranium cultivars that exhibit differential reactions to floral inoculation with Botrytis cinerea Per. ex. Fr. Sixty-two genotypes, including both cultivars and breeding lines, were evaluated from several Pelargonium species. Resistant genotypes included the diploid Pelargonium peltatum $(\mathrm{L}$.) L'Herit. cultivar King of Balcon and the diploid Pelargonium $\times$ hortorum L.H. Bail. cultivar Ben Franklin, as well as the diploid Pelargonium peltatum accession 93-1-33 developed from an accession obtained from South Africa. Susceptible genotypes included the putative tetraploid Pelargonium peltatum cultivar Simone. Floral resistance was not correlated with foliar resistance. Diploid genotypes appeared to have greater resistance than tetraploid genotypes, and $\boldsymbol{P}$. peltatum cultivars more resistance than $\boldsymbol{P}$. $\times$ hortorum cultivars. In addition, the association of petal number and resistance was investigated.
\end{abstract}

Botrytis blight or gray mold, caused by the fungus Botrytis cinerea, is one of the most common diseases of the zonal geranium. Flowers, foliage, stems, cuttings, and stock plants are all susceptible to attack by this pathogen. Hausbeck(1990) estimated that, in 1985, losses of geranium due to $B$. cinerea infection were \$U.S. 0.7 to 1.1 million in Pennsylvania and between $\$ 5.1$ and 7.6 million in the United States.

Flowers of many crops have been studied in an attempt to elucidate the mechanism(s) of resistance to Botrytis (Hammer and Evensen, 1994; Pie and De Leeuw, 1991; Salinas and Verhoeff, 1995; Sirjusingh and Sutton, 1996). Investigations into the Pelargonium-Botrytis pathosystem have been ongoing for many years. The initial description of the disease's epidemiology was provided by L.E. Melchers in 1918. Melchers noted that petals were the first tissue infected, and, as they abscised and dropped on the leaves, served as a nutrient

Received for publication 25 Aug. 1997. Accepted for publication $25 \mathrm{Sept}$. 1998. The use of trade names in this publication does not imply endorsement of the products named, nor criticism of similar ones not mentioned. We acknowledge the technical assistance of Angelica Zhigilei, and support from the American Floral Endowment, the Fred C. Gloeckner Foundation, the Intercollege Degree Program in Genetics and the Department of Horticulture. We also thank Oglevee Ltd. for their generous donation of plant material. This paper is based on a portion of a thesis submitted by the senior author in partial fulfillment of the requirements for the $\mathrm{PhD}$ degree. The cost of publishing this paper was defrayed in part by the payment of page charges. Under postal regulations, this paper therefore must be hereby marked advertisement solely to indicate this fact.

${ }^{1}$ Current address: PanAmerican Seed Co., 1S861 Green Rd., Elburn, IL 60119.

${ }^{2}$ Current address: 3205 Lambros Dr., Midland, MI 48642.

${ }^{3}$ Professor. base for further fungal infection. Free water is required for infection by Botrytis (Salinas and Verhoeff, 1995), and at $21{ }^{\circ} \mathrm{C}$ a minimum wetness duration of $4 \mathrm{~h}$ is required for infection in Pelargonium (Sirjusingh and Sutton, 1996). Pie and De Leeuw (1991) observed direct penetration of rose (Rosa hybrida L.) petal cuticle through the formation of an infection peg, followed by the rapid degradation of the epidermal cell walls once the cuticle was penetrated. Salinas and Verhoeff (1995) observed direct penetration of Gerbera (Gerbera $\times$ hybrida Hort.) petal cells, but the fungus did not form specialized structures and the cuticle did not appear to be degraded. Additionally, the presence of ethylene may play a role in disease establishment, as both rose and carnation (Dianthus caryophyllus L.), grown as cut flowers, were more susceptible to $B$. cinerea in the presence of ethylene (Elad, 1988).

Our approach initially was not to characterize the mechanism(s) in Pelargonium, but to evaluate the range of genetic floral resistance to $B$. cinerea. Cultivars with floral resistance may reduce the incidence of foliar infection by reducing the overall spore load within the greenhouse. While floral resistance to $B$. cinere $a$ has been studied in many horticultural crops, few studies have evaluated multiple genotypes. There is some evidence of genetic variation for floral resistance to Botrytis among rose cultivars (Hammer and Evensen, 1994). Our objective was to compare 62 Pelargonium genotypes for genetic differences in floral resistance to Botrytis. We also investigated the association between resistance and ploidy levels, date of cultivar introduction, and species.

\section{Materials and Methods}

Plant culture. Sixty-two Pelargonium genotypes were grown under natural irradiance in a greenhouse at the Pennsylvania State
Univ. in 15-cm standard pots using Premier Pro-Mix BX (Premier Horticulture, Red Hill, Pa.) media. Plants were irrigated as needed and fertilized at each irrigation with Peter's Excel 15-5-15 (Scott Sierra, Marysville, Ohio) at a rate of $200 \mathrm{mg} \cdot \mathrm{L}^{-1} \mathrm{~N}$. Temperature set points were $21^{\circ} \mathrm{C}$ day $/ 17^{\circ} \mathrm{C}$ night, although these limits were often exceeded. Insect and arthropod pests were controlled using standard practices.

Pathogen culture. An isolate (M1) of Botrytis cinerea was collected as a single spore isolate from Botrytis-infected Pelargonium in a research greenhouse at the Pennsylvania State Univ. Conidia from this culture were put in long-term storage at $4{ }^{\circ} \mathrm{C}$ and the same isolate was used in all experiments. Cultures were initiated on a low-nutrient media composed of $20 \mathrm{~g}$ dextrose, $1 \mathrm{~g} \mathrm{~K}_{2} \mathrm{HPO}_{4}$, $0.5 \mathrm{~g} \mathrm{MgSO}_{4} \cdot 7 \mathrm{H}_{2} \mathrm{O}, 0.5 \mathrm{~g} \mathrm{KCl}, 0.01 \mathrm{~g}$ $\mathrm{FeSO}_{4} \cdot 7 \mathrm{H}_{2} \mathrm{O}, 1.7 \mathrm{~g}$ asparagine, and $20 \mathrm{~g}$ agar per liter of distilled water (Phillips et al., 1987). A 4-mm-diameter agar disk containing mycelium was used to inoculate leaves of the cultivar Ben Franklin. Leaves were incubated for $7 \mathrm{~d}$ at $21^{\circ} \mathrm{C}$ under high humidity and 14-h photoperiod with irradiance provided by coolwhite fluorescent tubes. After $7 \mathrm{~d}$, conidia were washed from the leaf surface with autoclaved distilled water and used for inoculations.

Inoculations. Inflorescences were harvested from greenhouse-grown geraniums for floral inoculations. Individual florets were removed from the inflorescence at anthesis and placed in racks in plastic crisper boxes containing enough water to keep the base of the pedicel submerged. Florets were spray-inoculated with a Botrytis solution containing 4000 conidia/mL, using a Preval spray unit (Precision Valve Corp., Yonkers, N.Y.) until droplets of water appeared on the petals. Plants were incubated in a growth chamber for $2 \mathrm{~d}$ at $21{ }^{\circ} \mathrm{C}$ under the same conditions used for incubating leaves. Florets were evaluated visually on the following scale: $1=$ no symptoms; $2=$ small lesions on a few petals, barely visible to the naked eye; $3=$ several small lesions, no lesions on at least one petal; $4=$ lesions on all petals; $5=$ many lesions, a few $>2$ $\mathrm{mm} ; 6=$ many lesions, several $>2 \mathrm{~mm} ; 7=$ some lesions $>4 \mathrm{~mm}$, and/or an entire petal blighted; $8=$ more than one petal entirely blighted; $9=$ at least four petals entirely blighted. A cultivar with resistant flowers (but susceptible foliage), 'Ben Franklin' (Braun, 1992), and noninoculated florets were included in each trial. At least five florets were evaluated for each accession in each replication and all experiments were repeated three times.

In a second method of inoculation, 10 petals were removed from geranium florets and placed on moist filter paper in a petri dish. Each petal was inoculated with a $10-\mathrm{mL}$ droplet of conidial suspension (4000 conidia/mL). Evaluations were made after $48 \mathrm{~h}$, and the total number of diseased petals were counted.

Cell measurements. Petals were removed from florets of eight cultivars and the size of individual epidermal petal cells was measured using an ocular micrometer and a compound 
microscope. The cells of 10 petals were measured from three florets for each of the eight genotypes.

Statistical analysis. Data from four experiments were combined into a single table, since differences among experiments within the control genotype ('Ben Franklin') were nonsignificant in a one-way analysis of variance. Data were standardized prior to analysis by dividing floral ratings by the standard deviation of the population of each experiment.

Orthogonal contrasts were performed utilizing the standardized data to make meaningful comparisons among the accessions listed in Table 1. All floral evaluations were conducted as a randomized complete-block design. Data were analyzed using the GLM procedure of the Statistical Analysis System (SAS Institute, Cary, N.C.).

\section{Results and Discussion}

A wide range of resistance was observed among genotypes, but none was immune. 'Ben Franklin' (diploid, $P$. $\times$ hortorum), and 'King of Balcon' and accession 93-1-33 (both diploid, $P$. peltatum) were among the highly resistant genotypes (Table 1), and the ivy geranium (P. peltatum) cultivar Simone was by far the most susceptible genotype evaluated.

Genotypes with a standardized resistance value of $<2$ should be considered highly resistant (Table 1), those with a value $>3$ are relatively susceptible, and genotypes with a standardized value $>4$ should be considered highly susceptible. This information should prove useful to those who conduct research on floral resistance to Botrytis within the genus Pelargonium, and to those who wish to choose relatively resistant cultivars for breeding or production purposes.

Results using two inoculation methods (floret inoculation vs. individual petals) were not strongly correlated $(r=0.51)$. Only the floret evaluation was used for all experiments because it reasonably simulated natural inoculation methods and was the easiest method to use when evaluating many samples. Our inoculum level (4000 conidia/mL) was relatively high. Sirjusingh et al. (1996) reported that 10 conidia/mL was sufficient for infection of geranium tissue (Sirjusingh et al., 1996), and Braun (1992) suggested that 2000 conidia/mL was appropriate. However, we observed slightly more consistent results with the higher level (data not shown).

'Ben Franklin' was used as a resistant control, although it was among the most susceptible genotypes identified in our evaluations for foliar resistance (Uchneat et al., 1999). In fact, there seems to be no correlation between foliar and floral resistance, and each type of resistance needs to be considered a separate genetic trait. This should come as no surprise, as the physiology of leaf and floral tissues differ. In fact, resistance has been observed to be dependent on tissue and developmental stage in other crops (Ma and Singh, 1996; Makowski, 1993).

As Botrytis conidia germinate, the germ tube grows along the junctures of cells prior to
Table 1. Floral evaluations for resistance to Botrytis of greenhouse-grown pelargoniums ranked by standardized values (Std X) from four experiments. Genotypes with the greatest floral resistance are listed at the top of the table. Actual values (X) in each experiment are provided along with the standard error (SE of $\mathrm{X}$ ) of the mean for these values.

\begin{tabular}{|c|c|c|c|c|c|c|}
\hline Genotype & Species & Ploidy & Year $^{2}$ & Std X & $\mathrm{X}^{\mathrm{y}}$ & SE of $X$ \\
\hline King of Balcon & P. peltatum & $2 x$ & $<1990^{x}$ & 1.10 & 1.70 & 0.21 \\
\hline $93-1-33$ & P. peltatum & $2 x$ & 1993 & 1.34 & 2.46 & 0.31 \\
\hline Ben Franklin & P. $\times$ hortorum & $2 x$ & 1987 & 1.41 & 2.58 & 0.32 \\
\hline Marilyn & floribunda & $2 x$ & 1990 & 1.45 & 2.87 & 0.42 \\
\hline $93-6-11$ & P. $\times$ hortorum & $2 x$ & 1993 & 1.57 & 2.89 & 0.42 \\
\hline Princess Balcon & P. peltatum & $2 x$ & $<1990$ & 1.59 & 2.92 & 0.38 \\
\hline $86-23-1$ & P. peltatum & $2 x$ & 1986 & 1.62 & 2.50 & 0.38 \\
\hline $93-1-29$ & $P$. peltatum & $2 x$ & 1993 & 1.63 & 3.00 & 0.55 \\
\hline $93-6-7$ & P. $\times$ hortorum & $2 x$ & 1993 & 1.83 & 3.36 & 0.66 \\
\hline P. acreum & P. acreum & $2 x$ & --- & 1.86 & 3.00 & 0.53 \\
\hline Ritz & P. $\times$ hortorum & $4 x$ & 1992 & 1.95 & 3.87 & 0.70 \\
\hline $93-1-4$ & P. peltatum & $2 x$ & 1993 & 1.98 & 3.63 & 0.50 \\
\hline Minicascade Red & P. peltatum & $2 x$ & $<1990$ & 2.01 & 3.10 & 0.47 \\
\hline Minicascade Pink & P. peltatum & $2 x$ & $<1990$ & 2.02 & 3.71 & 0.50 \\
\hline P. tongaense & P. tongaense & $2 \mathrm{x}$ & --- & 2.09 & 3.38 & 0.57 \\
\hline Minicascade Lavender & $P$. peltatum & $2 x$ & $<1990$ & 2.26 & 3.50 & 0.81 \\
\hline P. zonale & P. zonale & $2 x$ & --- & 2.26 & 3.65 & 0.51 \\
\hline $93-5-4$ & P. $\times$ hortorum & $2 x$ & 1993 & 2.27 & 3.67 & 0.54 \\
\hline $93-2-2$ & P. $\times$ hortorum & $2 x$ & 1993 & 2.30 & 3.72 & 0.45 \\
\hline Elizabeth & floribunda & $2 x$ & 1993 & 2.45 & 4.86 & 0.61 \\
\hline $93-3-1$ & P. $\times$ hortorum & $2 x$ & 1993 & 2.48 & 4.00 & 0.48 \\
\hline $93-5-2$ & P. $\times$ hortorum & $2 x$ & 1993 & 2.52 & 4.06 & 0.66 \\
\hline $84-72-5$ & P. $\times$ hortorum & $4 x$ & 1984 & 2.54 & 3.92 & 0.57 \\
\hline $93-6-10$ & P. $\times$ hortorum & $2 \mathrm{x}$ & 1993 & 2.54 & 4.67 & 0.66 \\
\hline $93-2-3$ & P. $\times$ hortorum & $2 x$ & 1993 & 2.55 & 4.11 & 0.57 \\
\hline $93-5-1$ & P. $\times$ hortorum & $2 x$ & 1993 & 2.58 & 4.17 & 0.54 \\
\hline Double Lilac White & P. peltatum & $4 x$ & $<1971$ & 2.59 & 4.75 & 0.59 \\
\hline Nicole & P. peltatum & $4 x$ & 1990 & 2.60 & 4.78 & 0.74 \\
\hline Sunbelt Coral & P. $\times$ hortorum & $4 x$ & 1986 & 2.60 & 5.15 & 0.72 \\
\hline $93-5-10$ & P. $\times$ hortorum & $2 x$ & 1993 & 2.66 & 4.89 & 0.50 \\
\hline Tetra Scarlet & P. $\times$ hortorum & $4 x$ & $>1990$ & 2.70 & 4.17 & 0.71 \\
\hline $93-6-6$ & P. $\times$ hortorum & $2 x$ & 1993 & 2.85 & 5.23 & 0.66 \\
\hline Mrs. Parker & P. $\times$ hortorum & $2 x$ & 1893 & 2.86 & 5.25 & 0.57 \\
\hline Sunset & P. $\times$ hortorum & $4 x$ & 1991 & 2.86 & 5.67 & 0.65 \\
\hline Fox & P. $\times$ hortorum & $4 x$ & 1989 & 2.91 & 4.50 & 0.32 \\
\hline Salmon Queen & P. peltatum & $4 x$ & $<1990$ & 2.92 & 5.78 & 0.74 \\
\hline Grace & floribunda & $2 \mathrm{x}$ & 1990 & 3.03 & 6.00 & 0.58 \\
\hline Melody & P. $\times$ hortorum & $4 x$ & 1992 & 3.07 & 6.07 & 0.60 \\
\hline Fame & P. $\times$ hortorum & $4 x$ & --- & 3.09 & 4.77 & 0.50 \\
\hline Danielle & P. $\times$ hortorum & $4 x$ & 1987 & 3.13 & 6.20 & 0.50 \\
\hline $93-3-5$ & P. $\times$ hortorum & $2 x$ & 1993 & 3.14 & 5.06 & 0.55 \\
\hline $93-5-3$ & P. $\times$ hortorum & $2 x$ & 1993 & 3.14 & 5.06 & 0.70 \\
\hline Julia & floribunda & $2 \mathrm{x}$ & 1995 & 3.21 & 5.90 & 0.62 \\
\hline Precious & P. $\times$ hortorum & $4 x$ & 1992 & 3.30 & 6.53 & 0.52 \\
\hline Yours Truly & P. $\times$ hortorum & $4 x$ & $<1972$ & 3.34 & 5.17 & 0.57 \\
\hline Medallion Dark Red & P. $\times$ hortorum & $4 x$ & 1993 & 3.38 & 5.22 & 0.62 \\
\hline Juliet & P. $\times$ hortorum & $4 x$ & 1989 & 3.38 & 6.70 & 0.83 \\
\hline $93-5-5$ & P. $\times$ hortorum & $2 x$ & 1993 & 3.45 & 5.56 & 0.47 \\
\hline Judy & floribunda & $2 \mathrm{x}$ & 1990 & 3.47 & 6.87 & 0.57 \\
\hline P. multibracteatum & P. multibracteatum & $2 x$ & --- & 3.54 & 5.71 & 0.69 \\
\hline Angela & floribunda & $2 \mathrm{x}$ & 1995 & 3.56 & 5.50 & 0.50 \\
\hline Sassy Dark Red & P. $\times$ hortorum & $4 x$ & 1992 & 3.56 & 5.50 & 0.47 \\
\hline Veronica & P. $\times$ hortorum & $4 x$ & 1983 & 3.56 & 5.50 & 0.49 \\
\hline $93-3-2$ & P. $\times$ hortorum & $2 \mathrm{x}$ & 1993 & 3.61 & 5.83 & 0.44 \\
\hline White Nicole & P. peltatum & $4 x$ & 1990 & 3.76 & 6.90 & 0.59 \\
\hline Sincerity & P. $\times$ hortorum & $4 x$ & $<1968$ & 3.84 & 5.94 & 0.37 \\
\hline $93-3-9$ & P. $\times$ hortorum & $2 x$ & 1993 & 3.89 & 6.28 & 0.57 \\
\hline $93-3-7$ & P. $\times$ hortorum & $2 \mathrm{x}$ & 1993 & 4.01 & 6.47 & 0.64 \\
\hline Snowhite & P. $\times$ hortorum & $4 x$ & 1984 & 4.06 & 6.28 & 0.60 \\
\hline P. inquinans & P. inquinans & $2 x$ & --- & 4.06 & 6.56 & 0.53 \\
\hline Pink Expectations & P. $\times$ hortorum & $4 x$ & 1984 & 4.10 & 6.33 & 0.49 \\
\hline Simone & P. peltatum & $4 x$ & 1990 & 5.25 & 8.11 & 0.26 \\
\hline Mean & & & & $\overline{2.82}$ & & \\
\hline $\operatorname{LSD}_{0.05}$ & & & & 0.71 & & \\
\hline
\end{tabular}

${ }^{z}$ Year patented (if available) or introduced, data were obtained from Craig (1993) and Linda Wiles (personal communication) of Oglevee Ltd.

${ }^{\mathrm{y}} 1=$ no symptoms; $2=$ small lesions on a few petals, barely visible to the naked eye; $3=$ several small lesions, no lesions on at least one petal; $4=$ lesions on all petals; $5=$ many lesions; a few greater than $2 \mathrm{~mm} ; 6=$ many lesions, several greater than $2 \mathrm{~mm} ; 7=$ some lesions greater than $4 \mathrm{~mm}$, and/or an entire petal blighted; 8 $=$ more than one petal entirely blighted; $9=$ at least four petals entirely blighted.

" "<" indicates a release prior to this year, but exact date unknown. 
Table 2. Comparison of Pelargonium cultivars categorized into various classes and compared for relative floral Botrytis resistance by using orthogonal contrasts and standardized Botrytis resistance ratings.

\begin{tabular}{lc}
\hline \hline Comparison and mean values $^{\mathrm{z}}$ & $P$ value \\
\hline Diploid cultivars (2.34) vs. tetraploid cultivars (3.18) & $<0.00$ \\
P. Xhortorum (3.11) vs. P. peltatum (2.61) & 0.05 \\
Floribundas (2.86) vs. P. peltatum (2.61) & 0.98 \\
P. Xhortorum (3.11) vs. floribundas (2.86) & 0.67 \\
Cultivars since 1990 (3.18) vs. older cultivars (2.74) & 0.40 \\
Single-flowered (2.43) vs. double-flowered genotypes $(2.98)^{\mathrm{y}}$ & 0.10 \\
Single-flowered (3.07) vs. double-flowered genotypes $(2.57)^{\mathrm{x}}$ & 0.01 \\
\hline
\end{tabular}

${ }^{2}$ Numbers in parentheses are mean standardized resistance ratings for that category.

${ }^{y}$ All genotypes.

'Only crosses involving 'Marilyn' and 'Ben Franklin'.

infection (Kamoen, 1992). We have observed this type of growth in Pelargonium tissue, but not exclusively (data not shown). Measurements were made on cell size (data not shown) with the expectation that smaller cells might have more cell junctures, which would be favorable to Botrytis germlings. However, the correlation between cell size and relative floral resistance to Botrytis was nonsignificant $(r$ $=0.57, P=0.14)$ among eight genotypes. This coefficient increased to $r=0.78(P=0.04)$ when the cultivar Marilyn was removed from the analysis. In the latter case, smaller-celled cultivars had slightly better Botrytis resistance.

Diploid cultivars appeared to have greater resistance than tetraploid genotypes across all species and flower types (Table 2). Both single(5 petals) and double- ( $>5$ petals) flowered genotypes existed in each class (diploid and tetraploid). Pelargonium peltatum genotypes had greater resistance than $P$. $\times$ hortorum genotypes, but the ivy geranium group was composed of primarily single-flowered genotypes, including some that were Penn State floralresistant breeding lines. Single-flowered genotypes may have increased resistance, since the microclimate may be less humid in areas where only five petals exist compared to 10 or more petals. However, examination of progeny of crosses between 'Ben Franklin' and 'Marilyn' showed that double-flowered genotypes had greater resistance than did single-flowered ones with similar genetic backgrounds, although the sample size was small (11 progeny).

Pelargonium inquinans (L.) L'Herit. and Pelargonium zonale (L.) L'Herit. are generally considered to be the two most important progenitors of $P$. ×hortorum (Harvey and Saunder, 1894; Horn, 1993). Pelargonium zonale was significantly more resistant to Botrytis than was $P$. inquinans. Several genotypes of $P$. zonale should be evaluated for Botrytis resistance, as these genotypes are easily cross-pollinated with most diploid cultivars and could provide greater resistance. This contrasts with mite resistance, where $P$. inquinans contributes resistance (Grazzini, 1993; Schultz, 1996).

Significant variation in Botrytis resistance was observed among the genotypes, suggesting that cultivars with greater Botrytis resistance can be developed. Data presented provide a scientific basis for selecting future parents. The identification of control genotypes for evaluating Botrytis resistance will be immensely valuable for future experiments.

\section{Literature Cited}

Braun, H.L. 1992. Host plant resistance of Pelargonium to Botrytis cinerea. MS Thesis, The Pennsylvania State Univ., University Park.

Craig, R. 1993. Intellectual property protection of Pelargoniums. HortTechnology 3:284-290.

Elad, Y. 1988. Involvement of ethylene in the disease caused by Botrytis cinerea on rose and carnation flowers and the possibility of control. Ann. Appl. Biol. 113:589-598.

Grazzini, R.A. 1993. A biochemical, evolutionary and genetic model of glandular trichome mediated small pest resistance in Pelargonium Xhortorum. PhD Diss., The Pennsylvania State Univ., University Park.

Hammer, P.E. and K.B. Evensen. 1994. Differences between rose cultivars in susceptibility to infection by Botrytis cinerea. Phytopathology 84:1305-1312.
Harvey, W.H. and O.W. Saunder. 1894. Flora Capensis. Vol. 1. L. Reeve and Co. Lloyds Bank Building, Bank St., Ashford, Kent, U.K.

Hausbeck, M.K. 1990. The epidemiology of Botrytis cinerea Pers. on the geranium (Pelargonium $\times$ hortorum L.H. Bailey). PhD Diss., The Pennsylvania State Univ., University Park.

Horn, W. 1993. Genetics and crossability of pelargoniums, p. 33-48. In:R.Craig (ed.). Proc.Third Intl. Geranium Conf. Ball Publ., Batavia, Ill.

Kamoen, O. 1992. Botrytis cinerea: Host-pathogen interactions, p. 39-47. In: K. Verhoeff, N.E. Malathrakis, and B. Williamson (eds.). Recent advances in Botrytis research. Pudoc Scientific Publ., Wageningen, The Netherlands.

Ma, H. and R.P. Singh. 1996. Expression of adult resistance to stripe rust at different growth stages of wheat. Plant Dis. 80:375-379.

Makowski, R.M.D. 1993. Effect of inoculum concentration, temperature, dew period, and growth stage on disease of round leaved mallow and velvetleaf by Colletotricum gloeosporioides $\mathrm{f}$. sp. malvae. Phytopathology 83:1229-1234.

Melchers, L.E. 1918. Botrytis sp. causing severe injury to flowers and foliage of Pelargonium hortorum. Phytopathology 8:76.

Phillips, D.J., D.A. Margosan, and B.E. Mackey. 1987. Size, number, and aggressiveness of Botrytis cinerea spores produced on media of various glucose concentrations. Phytopathology 77:1606-1608.

Pie, K. and G.T.N. De Leeuw. 1991. Histopathology of the initial stages of the interaction between rose flowers and Botrytis cinerea. Neth. J. Plant Pathol. 97:335-344.

Salinas, J. and K. Verhoeff. 1995. Microscopical studies of the infection of gerbera flowers by Botrytis cinerea. European J. Plant Pathol. 101:377-386.

SAS Institute. 1988. SAT/STAT user's guide: Release 6.03 ed. SAS Inst., Cary, N.C.

Schultz, D.J. 1996. Molecular and biochemical evaluation of fatty acid desaturase genes that influence the production of anacardic acids in geranium. PhD Diss., The Pennsylvania State Univ., University Park.

Sirjusingh, C. and J.C. Sutton. 1996. Effects of wetness duration and temperature on infection of geranium by Botrytis cinerea. Plant Dis. 80:160-165.

Sirjusingh, C., J.C. Sutton, and M.J. Tsujita. 1996. Effects of inoculum concentration and host age on infection of geranium by Botrytis cinerea. Plant Dis. 80:154-159.

Uchneat, M.S., A. Zhigilei, and R. Craig. 1999. Differential response to foliar infection by Botrytis cinerea within the genus Pelargonium. J. Amer. Soc. Hort. Sci. 124:76-80. 